\title{
Mammalian humerus from the Early Cretaceous of West Siberia
}

\author{
Petr P. Gambaryan, Alexander O. Averianov, Evgeny N. Maschenko \\ \& Sergei V. Leshchinskiy
}

\begin{abstract}
A distal humerus fragment from the Early Cretaceous Shestakovo locality in Kemerovo Province, West Siberia is described and referred to "Symmetrodonta". This humerus is characterized by relatively narrow distal epiphysis, large entepicondylar foramen, globular radial condyle, ellipsoidal ulnar condyle, coalesced articular surfaces of both condyles, and a unique additional articular platform for the radius laterally to the radial condyle. This structure of the elbow joint is structurally intermediate between cynodonts, morganucodontids, and multituberculates on the one hand and crown Theria on the other. Among mammals with the similar structure of the elbow joint the humerus from Shestakovo is most similar with the humerus of the Early Cretaceous "symmetrodont"Zhangheotherium from China, and it might belong to a new tinodontid "symmetrodont" being described from the same locality on dental remains.
\end{abstract}

KEY WORDS: Humerus, anatomy, musculature, "Symmetrodonta”, Early Cretaceous, West Siberia.

Petr P. Gambaryan [gambar@PG5237.spb.edu], Zoological Institute, Russian Academy of Sciences, Universitetskaya nab. 1, Saint Petersburg 199034,Russia; Alexander O. Averianov [sasha@,AA1923.spb.edu], Zoological Institute, Russian Academy of Sciences, Universitetskaya nab. 1, Saint Petersburg 199034, Russia; Evgeny N. Maschenko [evmasch@paleo.ru], Paleontological Institute, Russian Academy of Sciences, Profsouznaya ul. 123, Moscow 117868, Russia; Sergei V. Leshchinskiy [sl@ggf.tsu.ru], Department of Palaeontology and Historical Geology, Geological-Geographical Faculty, Tomsk State University, Prospekt Lenina 36, Tomsk 634050, Russia.

\section{Плечевая кость млекопитающего из раннего мела Западной Сибири}

\author{
П.П. Гамбарян, А.О. Аверьянов, Е.Н. Мащенко, С.В. Лещинский
}

РЕЗЮМЕ. ОПисан и отнесен к “симметродонтам” дистальный фрагмент плечевой кости из раннемелового местонахождения Шестаково (Кемеровская область, Западная Сибирь). Плечевая кость характеризуется относительно узким дистальным эпифизом, большим энтепикондилярным отверстием, глобулярным радиальным мыщелком, эллипсовидным ульнарным мыщелком, соединенной сочленовной поверхностью обоих мыщелков и уникальной добавочной площадкой для лучевой кости латеральнее лучевого мыщелка. Такое строение локтевого сустава является структурно промежуточным между строением у цинодонтов, морганукодонтид, мультитуберкулят, с одной стороны и кроновых терий, с другой стороны. Среди млекопитающих со сходным строением локтевого сустава плечевая кость из Шестаково наиболее близка к плечевой кости раннемелового “симметродонта" Zhangheotherium из Китая; она может принадлежать новому тинодонтидному “симметродонту”, описываемому из того же местонахождения по зубным остаткам.

КЛЮЧЕВЫЕ СЛОВА: Плечевая кость, анатомия, мускулатура, “Symmetrodonta”, ранний мел, Западная Сибирь.

\section{Introduction}

The Early Cretaceous fossil localities around Shestakovo village in Kemerovo Province, West Siberia are renowned for diverse vertebrate fauna, including fishes, salamanders, turtles, lizards, crocodylomorphs, dinosaurs, birds, cynodonts, and various mammals. The mammals are the most important component of the fauna as until very recently little was known about the mammal evolution in the Early Cretaceous. Mammal assemblage from Shestakovo consists of "triconodonts" Amphilestidae indet., Gobiconodon spp., a docodont Sibirotherium rossicus, a "symmetrodont" Tinodontidae gen. \& sp. n., and a peramuran Kiyatherium cardiodens (Maschenko, 1999a, b; Maschenko \& Lopatin, 1998; Maschenko etal., 2000, 2002a, b, 2003; Maschenko \& Voronkevich, 2001; Lopatin et al., in press). These identifications are based on dental remains, but a number of isolated mammalian postcranial elements are known from the locality as well. Here we describe one of the most complete and identifiable postcranial elements recovered from Shestakovo up to date, a distal humerus fragment, and discuss its possibly phylogenetic attribution.

Institutional abbreviations: PM TGU - Paleontological Museum, Tomsk State University, Tomsk, Russia; ZIN Zoological Institute, Russian Academy of Sciences, SaintPetersburg, Russia. 


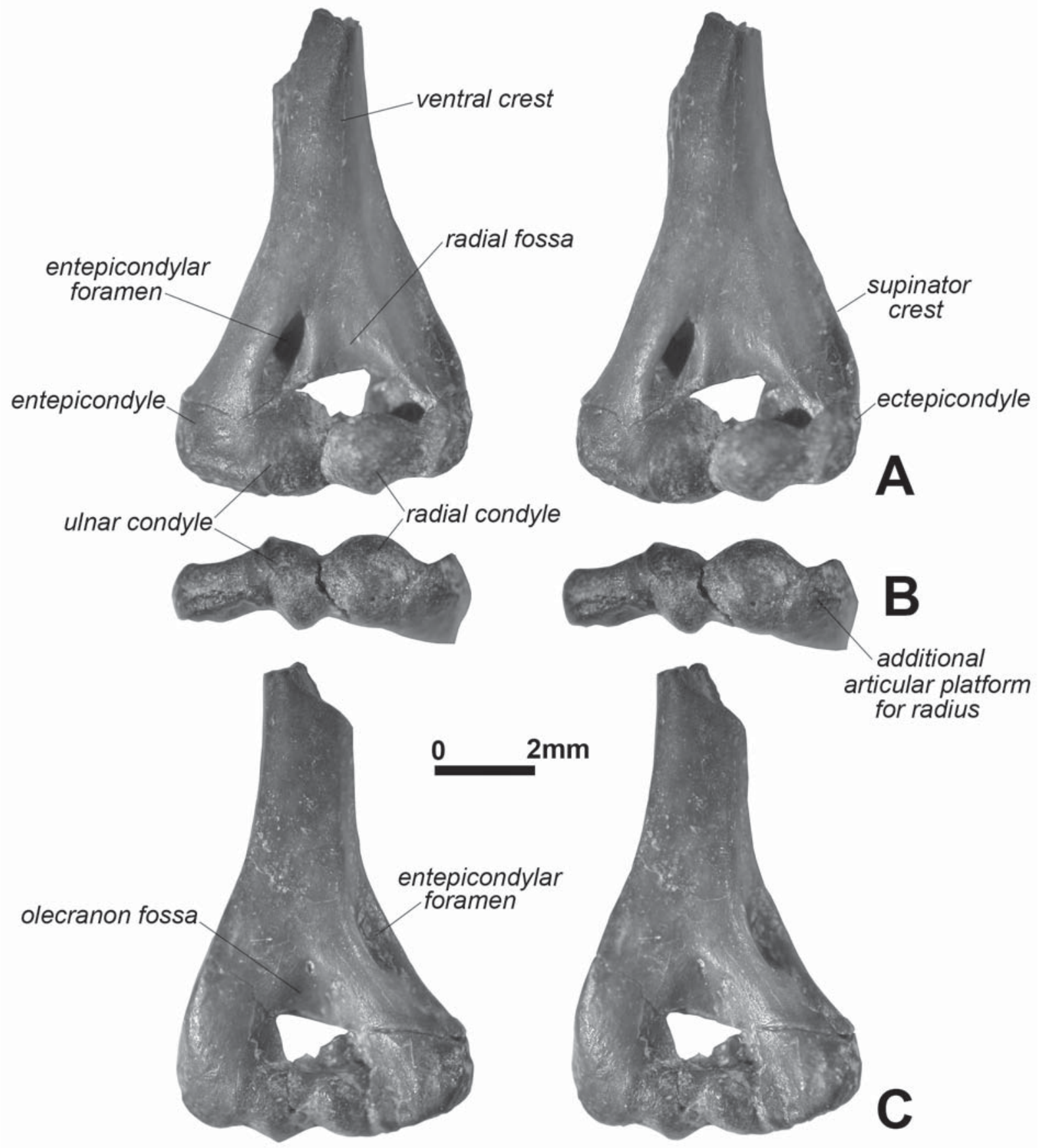

Figure 1. PM TGU 16/5-12, left humerus distal fragment, in ventral (anterior) (A), distal (B), and dorsal (posterior) (C) views. Shestakovo 1, Kemerovo Province, Russia; Ilek Formation, Lower Cretaceous. Stereopairs.

\section{Description}

Material. PM TGU 16/5-12, distal fragment of a left humerus. Shestakovo 1, approximately $40 \mathrm{~km}$ south of Mariinsk city, Chebula District, Kemerovo Province, Russia; Ilek Formation, Lower Cretaceous, Aptian-Albian.

Description(Fig. 1). The humerus shaft is relatively thin, more than three times narrower than the distal epiphysis. It is triangular in cross section, with flat dorsal (posterior) side and a strong ventral (anterior) crest continuing proximally to the missing deltopectoral crest. The entepicondylar flange is twice as large as the ectepicondylar flange, mostly due to the enlarged entepicondyle. The supinator crest is prominent and laminar, with a sigmoidal profile. It does not extend proximally much beyond the distal epiphysis. A large entepicondylar foramen is located above the entepicondyle. This 


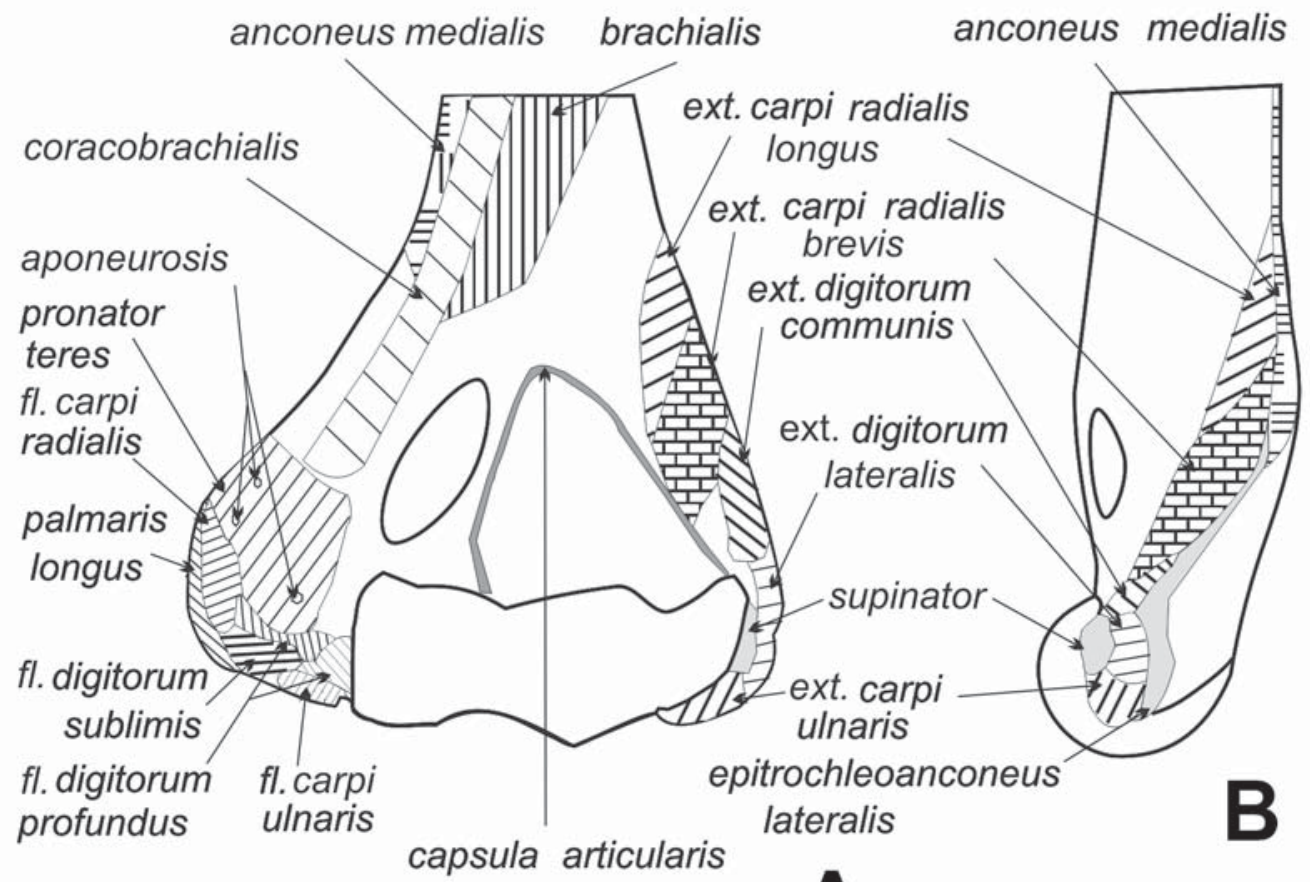

$5 \mathrm{~mm} \quad \mathbf{A}$

0

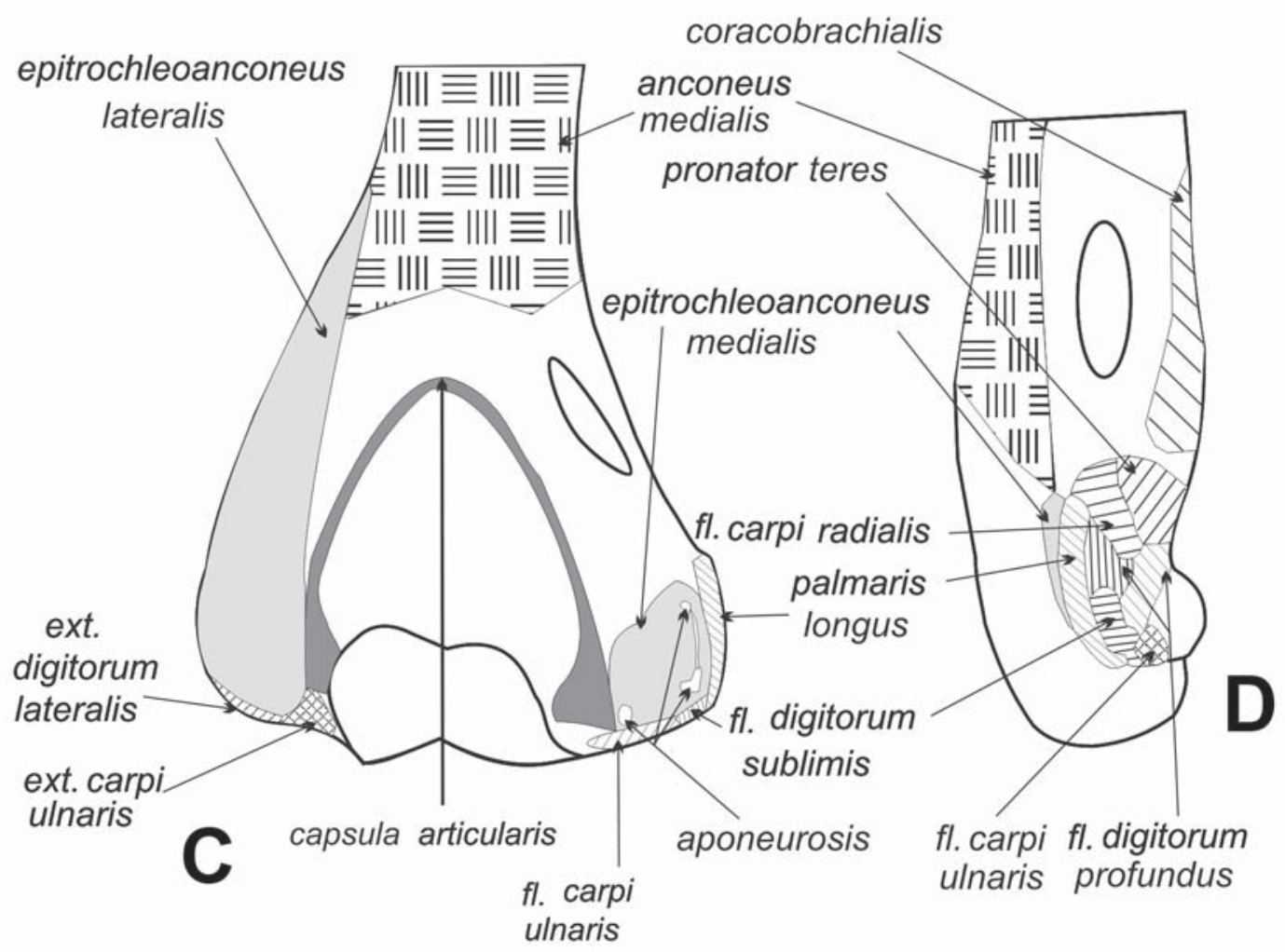

Figure 2. Reconstruction of muscles attachment areas in PM TGU 16/5-12 in ventral (anterior) (A), lateral (B), dorsal (posterior) (C), and medial (D) views. 
foramen opens on the ventral side rather close to the humerus midline and delimited medially by a robust bony bridge. There is no ectepicondylar foramen. The radial condyle (capitulum) is spherical and prominent. Laterally to the radial condyle there is a narrow but distinct additional articular surface for the radius. The ulnar condyle is less spherical, dorsoventrally wider but mediolaterally narrower than the radial condyle. Its articular surface is delimited medially by a distinct notch. The articular surfaces of the radial and ulnar condyles are merged together without an intercondylar groove. Proximal to the condyles there are radial (supratrochlear) fossa on ventral side and olecranon fossa on dorsal side.

Measurements. Distal humerus width $5.7 \mathrm{~mm}$.

\section{Muscles reconstruction}

The bone surface in PM TGU 16/5-12 is well preserved that allow reconstruction of attachment areas for some muscles (Fig. 2). Humerus musculature of Norway rat (Rattus norvegicus Berkenhout, 1769) and longeared hedgehog (Hemiechinus auritus Gmelin, 1770) was used as modern models (Figs. 3, 4).

The attachment areas in PM TGU 16/5-12 can be most confidently reconstructed for the following muscles:

M. pronator teres. In rat and hedgehog there are two internal aponeuroses of $\mathrm{m}$. pronator teres with distinct roughness on the entepicondyle (Figs. 3, 4). Proximal to these aponeuroses $\mathrm{m}$. pronator teres has muscle attaching without trace on the bone surface. In PM TGU 16/5-12 there are three rather than two tuberosities that indicate presence of three aponeuroses of m. pronator teres (Fig. 2). Moreover, anterior to these tuberosities there is a platform most probably serving for attachment of the muscle part of $\mathrm{m}$. pronator teres. This platform is well delimited that, with the strong development of the internal aponeuroses of $\mathrm{m}$. pronator teres indicate reinforcement of this muscle in PM TGU 16/5-12.

M. supinator. In PM TGU 16/5-12 a rough attachment area of this muscle is well developed (Fig. 2). Among modern mammals, only monotremes have an additional articulation platform lateral to the radial condyle developed in connection with the forearm adduction and abduction. Accordingly, monotremes have well developed $\mathrm{m}$. pronator teres and $\mathrm{m}$. supinator, which have at least twice larger relative weight than in the majority of other studied mammals (Tab. 1). Topography of these muscles in monotremes allows forearm abduction from the plane of humerus movement additionally to the ulna rotation. Evidently, PM TGU 16/5-12 had reinforcement of both $\mathrm{m}$. pronator teres and $\mathrm{m}$. supinator.

M. epitrochleoanconeus medialis. In rat this muscle attachment area occupies medial edge of dorsal surface of the entepicondyle and extends on the medial margin of the humerus shaft (Fig. 3). In hedgehog it occupies only proximal half of the medial edge of the
Table 1. Percentage of $\mathrm{m}$. pronator teres $(\mathrm{A})$ and $\mathrm{m}$. supinator (B) to the weight of the forelimb muscles.

\begin{tabular}{|l|c|c|}
\hline Taxon & $\mathrm{A}, \%$ & $\mathrm{~B}, \%$ \\
\hline Zaglossus bruijni Peters \& Doria, 1876 & 2.1 & 1.1 \\
\hline Tachyglossus aculeatus Shaw, 1792 & 1.9 & 0.9 \\
\hline Lipotyphla (10 species) & $0.9-1.1$ & $0.4-0.5$ \\
\hline Rodentia (40 species) & $0.2-1.0$ & $0.1-0.4$ \\
\hline
\end{tabular}

entepicondyle (Fig. 4). In PM TGU 16/5-12 the attachment area of $\mathrm{m}$. epitrochleoanconeus medialis has a well developed tuberosity which indicates reinforcement of this muscle. It has three distinct aponeuroses (Fig. 2C) which increase pinnation of $\mathrm{m}$. epitrochleoanconeus medialis and thereby its strength. The tractive force of this muscle is directed medially to the plane of the humerus.

The functional peculiarities of the remaining muscles reconstructed in PM TGU 16/5-12 (Fig. 2) are less evident. Attachment areas for some of these muscles are conventionally reconstructed. Thus, $\mathrm{m}$. extensor carpi radialis longus et brevis, which are starting on the supinator crest by the external fascia, have no clear attachment structures there. In addition, attachment area of $\mathrm{m}$. flexor digitorum profundus is not clear.

\section{Locomotion}

A trochlea on the humerus in modern therians prevents all ulna movements in the elbow joint except the flexion-extension in the plane of the humerus movement. The distal humerus epiphysis in PM TGU 16/5-12 has a globular radial condyle and an ellipsoidal ulnar condyle. Laterally to the radial condyle there is an additional articular platform for the radius (Fig. 1B), similar to that observed in modern monotremes. In monotremes this platform is connected with the forearm movements aside the plane of the humerus movement (Jenkins, 1970; Pridmore, 1985). This additional articular surface for the radius lateral to the radial condyle in PM TGU 16/5-12, together with the extension of the ulnar articular surface medially, testify forearm movements aside the plane of the humerus movement. In one's turn, this indicates that during jumping asymmetrical locomotion the elbow joint was abducted aside from the parasagittal plane.

At the beginning of the support phase the forelimb is extending anteriorly and ventrally and settled almost in a parasagittal plane. During the second half of this phase, the elbow joint is shifting outwards in order to be on the parasagittal plane by the end of this phase. Analogous movement of the forelimbs was described for the multituberculates (Gambaryan \& Kielan-Jaworowska, 1997, fig.10). However, in multituberculates such a movement was provided by two almost globular condyles separated by a well-defined intercondylar groove. In PM TGU 16/ 5-12 these condyles are united by a common articulation surface and the ulnar condyle is narrower. This narrow- 


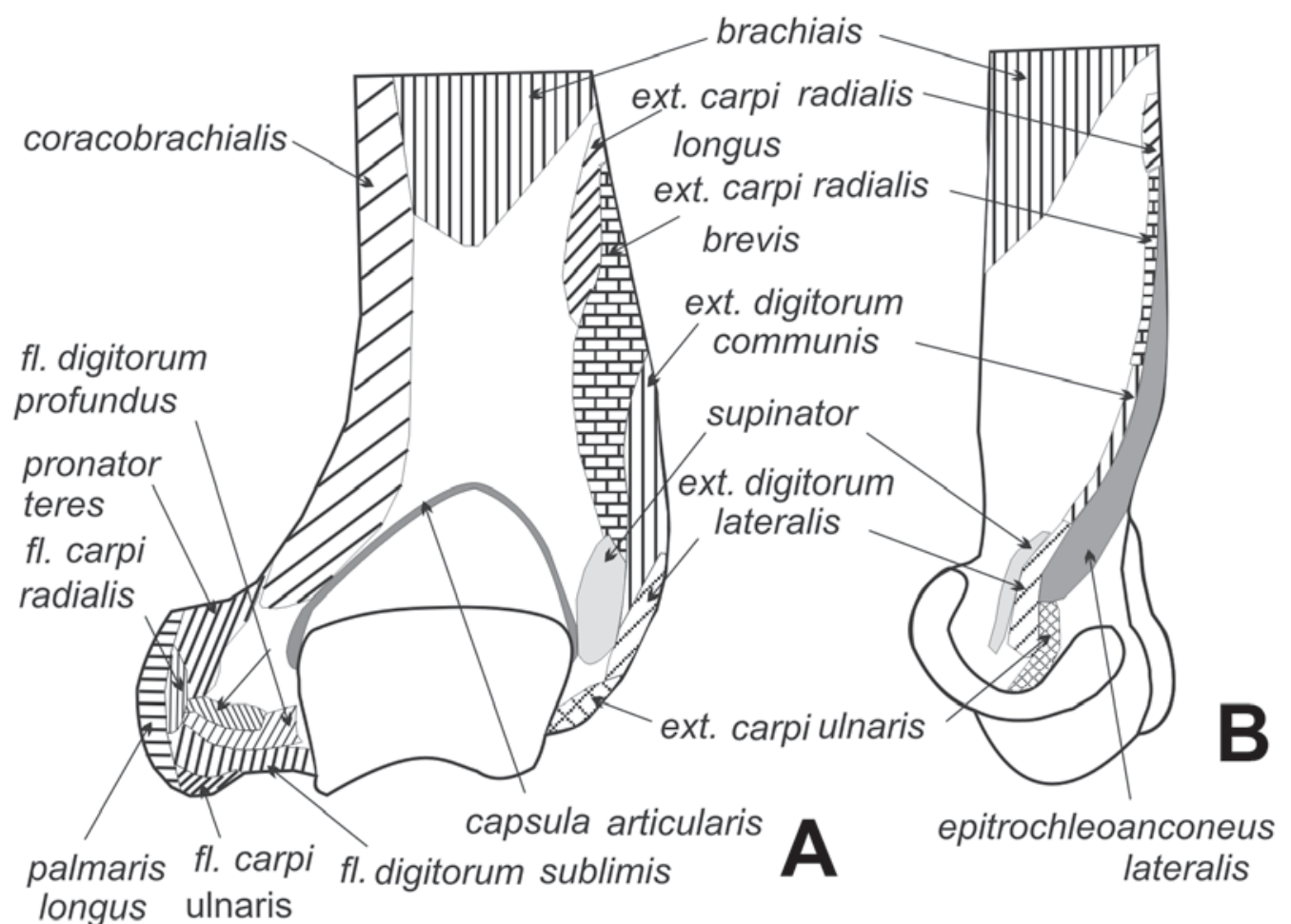

$0 \quad 5 \mathrm{~mm}$

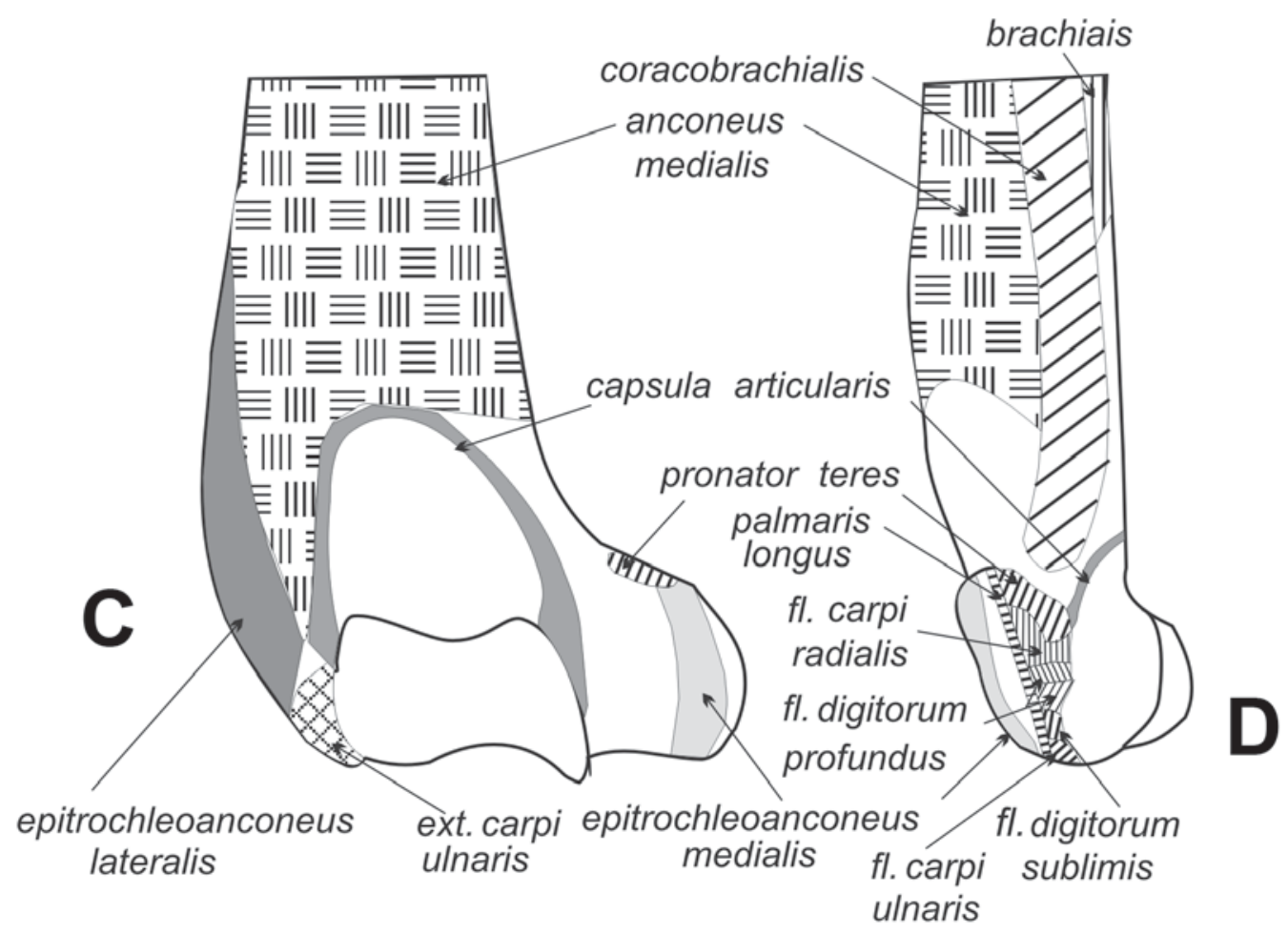

Figure 3. Muscles attachment areas in left distal humerus of Rattus norvegicus, ZIN 69108 in ventral (anterior) (A), lateral (B), dorsal (posterior) (C), and medial (D) views. 


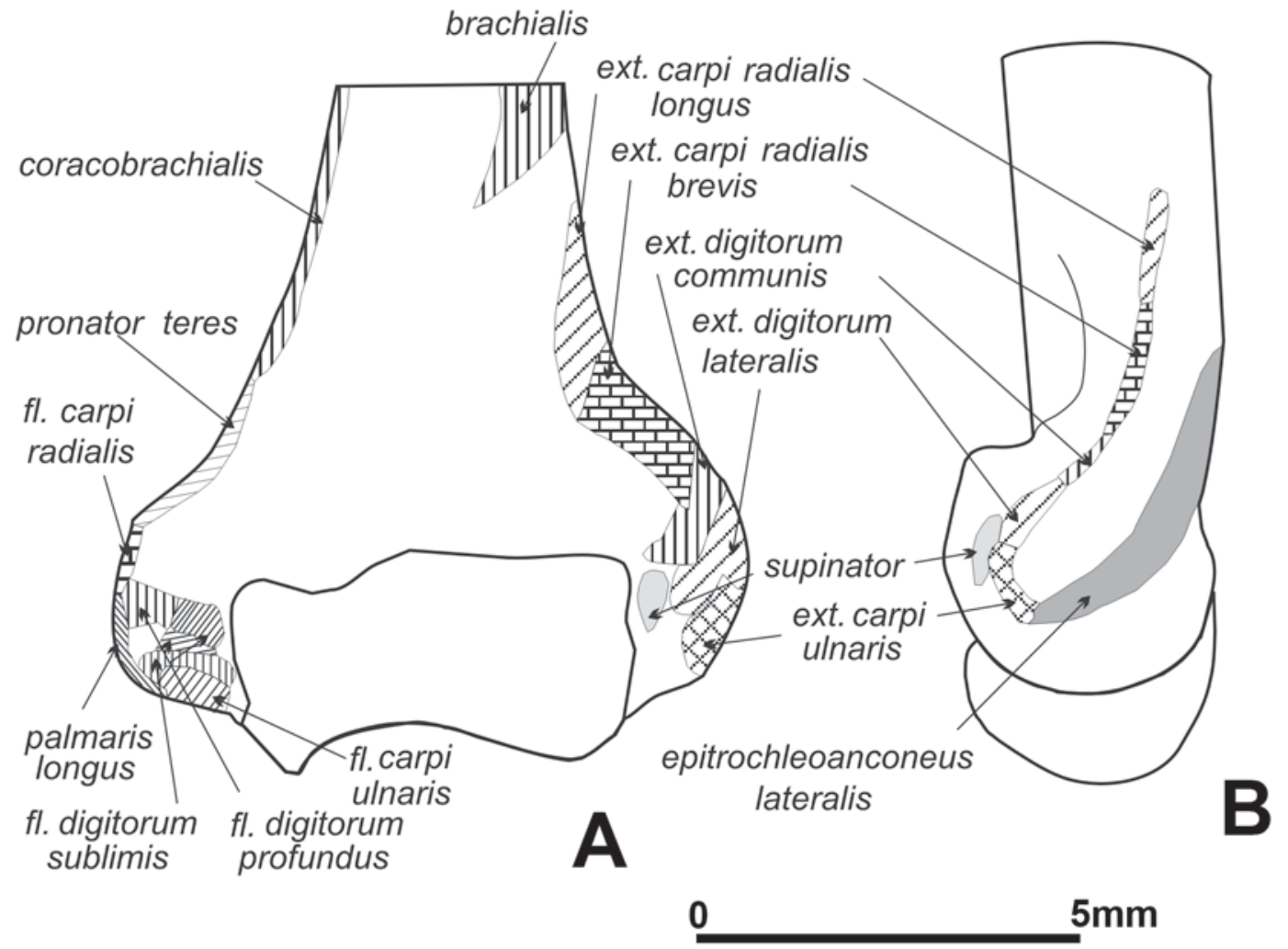

epitrochleoanconeus lateralis

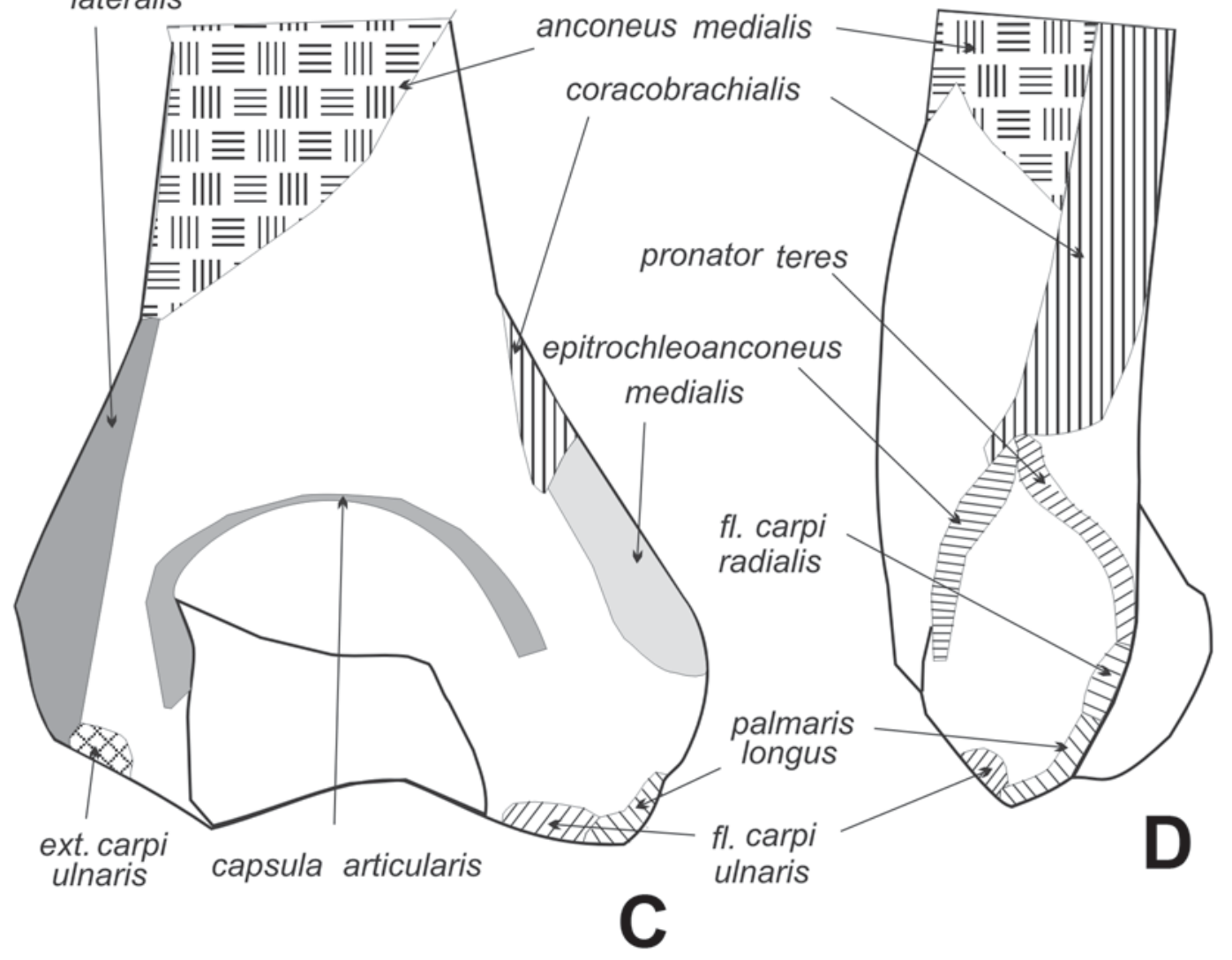

Figure 4. Muscles attachment areas in left distal humerus of Hemiechinus auritus, ZIN 65535 in ventral (anterior) (A), lateral (B), dorsal (posterior) (C), and medial (D) views. 
ness of the ulnar condyle must prevent from deviation of the ulna movement from the plane of the movement of the humerus and this might indicate more developed parasagittalism in PM TGU 16/5-12 compared to that in the multituberculates. The extent of deviation of the ulna during locomotion was similar in the multituberculates and in PM TGU 16/5-12 was similar, but achieved by different morphological structures: by separated condyles in multituberculates and by an additional articulation surface for the radius in PM TGU 16/5-12.

In PM TGU 16/5-12 the ridge of the ulnar condyle is directed at almost $45^{\circ}$ to the longitudinal axis of the humerus, which also indicate that ulna movement was not coincided with the plane of the humerus movement.

\section{Discussion}

Transformation of the humero-ulnar joint from condylar towards trochlear articulation was a key event in evolution of the mammal posture from sprawling stance with abducted limbs towards the parasagittal stance (Gambaryan \& Kielan-Jaworowska, 1997). During flexion-extension in the elbow joint with trochlear articulation the ulna moves in a parasagittal plane.

Whether the parasagittality was acquired by a common ancestor of modern therians or independently in a number of mammalian groups is a matter of controversy. Sereno \& McKenna (1995) argued that the forelimb stance in multituberculates was parasagittal and inherited from the common ancestor with therians. However, study of multituberculate skeleton by Kielan-Jaworowska \& Gambaryan (Kielan-Jaworowska \& Gambaryan, 1994; Gambaryan \& Kielan-Jaworowska, 1997; KielanJaworowska, 1998) showed that at least Asian multituberculates were adapted for asymmetrical jumps with abducted forelimbs. In any known multituberculate there is no trace of an incipient trochlea and the ulnar condyle is spherical and well developed. PM TGU $16 / 5-12$ is similar with multituberculates in retention of primitive condylar articulation with ulna, but differs in having condyles less spherical compared with the multituberculates, more narrow ulnar condyle, and having no deep intercondylar groove.

The condition of PM TGU 16/5-12 with strong radial condyle, weaker ellipsoidal ulnar condyle, and the coalesced articular surfaces of both condyles is structurally intermediate between cynodonts, morganucodontids, and multituberculates on the one hand and crown Theria on the other.

There are few other Mesozoic mammals which show similar intermediate condition of the elbow joint. One is eutriconodont Jeholodens Ji et al., 1999 from the Early Cretaceous of China (Jiet al., 1999) with weak ulnar and strong radial condyles on anterior (ventral) side, and an incipient ulnar trochlea posteroventrally. The humerus of Jeholodens differs from PM TGU 16/5-12 by having weaker developed entepi- and ectepicondyles. In habitual posture the forelimb of Jeholodens was reconstructed somewhat abducted, not fully parasagittal. A similar humerus structure was in a triconodontid Priacodon fruitaensis Rasmussen \& Callison, 1981 from the Late Jurassic of USA, but the entepicondyle was more developed (Engelmann \& Callison, 1998: fig.8). In a gobiconodontid Gobiconodon ostromi Jenkins \& Schaff, 1988 from the Early Cretaceous of Montana, USA (Jenkins \& Schaff, 1988) the ulnar condyle is not bulbous and this taxon might have an intermediate structure of the humero-ulnar joint. Humerus of G. ostromi, however, has a much wider distal epiphysis compared with PM TGU $16 / 5-12$, more projecting supinator crest, and very strong anterior crest continuing towards the entepicondyle. Gobiconodontids are the dominant mammal group in the Shestakovo fauna, but this dissimilarity prevents attribution of PM TGU 16/5-12 to this group. A unique character of PM TGU 16/5-12 is an additional articular surface for the radius lateral to the radial condyle. It was not described previously for any fossil mammal and found in modern monotremes.

Another taxon with intermediate structure of the elbow joint is "symmetrodont" Zhangheotherium Hu et al., 1997 from the Early Cretaceous of China (Hu et al., 1997, 1998). The humerus of Zhangheotherium is very similar with PM TGU 16/5-12, differs only in somewhat more robust shaft. It is likely that PM TGU 16/5-12 belongs to a "symmetrodont" mammal, which is known from the Shestakovo fauna by undescribed dentary with a rather complete dentition. Zhangheotherium was reconstructed as having noticeably abducted forelimbs. Similar, or semi-abducted forelimb posture can be inferred for the Shestakovo "symmetrodont".

"Symmetrodonts" are quite abundant in the Shestakovo fauna, being inferior only to the common sample of Gobiconodon spp., and represented by a new taxon of Tinodontidae (Lopatin et al., in press). No postcranial elements were previously reported for the Tinodontidae. Similarity of PM TGU 16/5-12 in morphology with the humerus in Zhangheotherium may indicate attribution of this specimen to a new tinodontid.

It is interesting to note that in a more derived "eupantotherian" mammal Henkelotherium Krebs, 1991 from the Late Jurassic of Portugal (Krebs, 1991; VásquezMolinero et al., 2001), the humerus has condylar articulation with ulna with fully separated radial and ulnar condyles. The spherical ulnar condyle was retained also in the "eupantotherian" Dryolestes leiriensis Martin, 1999 from the same beds in Portugal, but the intercondylar groove is weak there and it might had coalesced articular surfaces of both condyles (Martin, 2000: fig. 16.8). This, and variety of Early Cretaceous mammals with intermediate structure of the elbow joint (eutriconodont Jeholodens, "symmetrodont" Zhangheotherium and PM TGU 16/5-12) may suggest that the forelimb parasagittalism was acquired not in Late Jurassic (Gambaryan \& Kielan-Jaworowska, 1997), but somewhat later in the Early Cretaceous and possibly independently in different groups of mammals.

ACKNOWLEDGEMENTS. This work was supported by the President's of Russia grant MD-255.2003.04, by the Russian Fund of Basic Research grants 04-04-49113, 03-05- 
65340 and 04-04-49637, and by the Russian Science Support Foundation.

\section{References}

Engelmann G.F. \& Callison G.L. 1998. Mammalian faunas of the Morrison Formation // Carpenter K., Chure D.J. \& Kirkland J.I. (eds.). The Upper Jurassic Morrison Formation: An Interdisciplinary Study. Modern Geology. Vol.23. P.343-379.

Gambaryan P.P. \& Kielan-Jaworowska Z. 1997. Sprawling versus parasagittal stance in multituberculate mammals // Acta Palaeontologica Polonica. Vol.42. No.1. P.13-44.

Hu Y.-M., Wang Y.-Q., Luo, Z.-X. \& Li, C.-K. 1997. A new symmetrodont mammal from China and its implications for mammalian evolution // Nature. Vol.390. P.137-142.

Hu Y.-M., Wang Y.-Q., Li C.-K. \& Luo Z.-X. 1998. Morphology of dentition and forelimb of Zhangheotherium // Vertebrata PalAsiatica. Vol.36. No.2. P.102-125.

Jenkins F.A. Jr. 1970. Limb movements in a monotreme (Tachyglossus aculeatus): a cineradiographic analysis // Science. Vol.168. P.1473-1475.

Jenkins F.A. Jr. \& Schaff C.R. 1988. The Early Cretaceous mammal Gobiconodon (Mammalia, Triconodonta) from the Cloverly Formation in Montana // Journal of Vertebrate Paleontology. Vol.8. No.1. P.1-24.

Ji Q., Luo Z.-X. \& Ji S.-A. 1999. A Chinese triconodont mammal and mosaic evolution of mammalian skeleton // Nature. Vol.398. P.326-330.

Kielan-Jaworowska Z. 1998. Humeral torsion in multituberculate mammals // Acta Palaeontologica Polonica. Vol.43. No.1. P.131-134.

Kielan-Jaworowska Z. \& Gambaryan P.P. 1994. Postcranial anatomy and habits of Asian multituberculate mammals // Fossils and Strata. No.36. P.1-92.

Krebs B. 1991. Das Skelett von Henkelotherium guimarotae gen. et sp. nov. (Eupantotheria, Mammalia) aus dem Oberen Jura von Portugal // Berliner geowissenschaftliche Abhandlungen, Reihe A: Geologie und Paläontologie. Bd.133. S.1-121.

Lopatin A.V., Maschenko E.N., Averianov A.O., Rezvyi A.S., Skutschas P.P. \& Leshchinskiy S.V. In press. Early Cretaceous mammals from Western Siberia: 1. Tinodontidae // Paleontologicheskii Zhurnal. [in Russian].

Martin T. 2000. The dryolestids and the primitive "peramurid" from the Guimarota Mine // Martin T. \& Krebs B. (eds.). Guimarota: A Jurassic Ecosystem. Munich: Verlag Dr. Friedrich Pfeil. P.109-120.
Maschenko E.N. 1999a. [First record of an Early Cretaceous triconodont mammal (Mammalia, Triconodonta) in Siberia] // Byuleten' Moskovskogo Obschestva Ispytatelei Prirody, Otdel Geologicheskii. T.24. No.1. P.80 [in Russian].

Maschenko E.N. 1999b. [Mesozoic triconodont on the territory of Siberia] // Priroda. No.7. P.52-53 [in Russian].

Maschenko E.N. \& Lopatin A.V. 1998. First record of an Early Cretaceous triconodont mammal in Siberia// Bulletin de l'Institut Royal des Sciences Naturelles de Belgique, Sciences de la Terre. T.68. P.233-236.

Maschenko E.N., Lopatin A.V. \& Voronkevich A.V. 2000. [New Early Cretaceous mammals from the locality Shestakovo (Kemerovo Province)] // [Abstracts of Reports of 46th Session of the Paleontological Society]. Sankt Peterburg. P.61-62 [in Russian].

Maschenko E.N., Lopatin A.V. \& Voronkevich A.V. 2002a. [New Early Cretaceous mammal from Western Siberia] // Doklady Akademii Nauk. T.386. No.5. P.715-717 [in Russian].

Maschenko E.N., Lopatin A.V. \& Voronkevich A.V. 2003. A new genus of the tegotheriid docodonts (Docodonta, Tegotheriidae) from the Early Cretaceous of West Siberia // Russian Journal of Theriology. Vol.1. No.2. P.75-81.

Maschenko E.N. \& Voronkevich A.V. 2001. [New data on the diversity of mammals from the Early Cretaceous localities Shestakovo (south-west of Western Siberia)] // [Evolution of Life on the Earth. Materials of the Second International Symposium, November 12-15, 2001]. Tomsk: Izdatel'stvo NTL. P.448-450 [in Russian].

Maschenko E.N., Voronkevich A.V., Leshchinskiy S.V. \& Fayngerts A.V. 2002b. Early Cretaceous Shestakovo assemblage of mammalian fossils from Western Siberia // First International Palaeontological Congress (IPC2002). Geological Society of Australia, Abstracts. Sydney: McPherson's Printing Group. P.239-241.

Pridmore P.A. 1985. Terrestrial locomotion in monotremes (Mammalia: Monotremata) // Journal of Zoology, London. Vol.205. P.53-73.

Sereno P.C. \& McKenna M.C. 1995. Cretaceous multituberculate skeleton and the early evolution of the mammalian shoulder girdle // Nature. Vol.377. P.144-147.

Vázquez-Molinero R., Martin T., Fischer M.S. \& Frey R. 2001. Comparative anatomical investigations of the postcranial skeleton of Henkelotherium quimarotae Krebs, 1991 (Eupantotheria, Mammalia) and their implications for its locomotion// Mitteilungen aus dem Museum für Naturkunde in Berlin, Zoologische Reihe. Bd.77. Hf.2. P.207-216. 